157

Received: May 1, 2012

Accepted: November 30, 2012
Macedonian Journal of Animal Science, Vol. 3, No. 1, pp. 109-113 (2013)

In print ISSN $1857-6907$

On line ISSN $1857-7709$

UDC: $334.722-055.2: 316.334 .55(497.7)$

Original scientific paper

\title{
FEMALE ENTREPRENEURSHIP IN RURAL AREAS OF THE REPUBLIC OF MACEDONIA
}

\author{
Tošo Kostadinov \\ "Ss. Cyril and Methodius" University in Skopje, Institute of Animal Science, \\ Bul. Ilinden 92-a, Skopje, Republic of Macedonia \\ tosokostadinov@gmail.com
}

\begin{abstract}
The aim of this paper is to incorporate new elements in the corpus of knowledge about female entrepreneurship in rural areas of the Republic of Macedonia. In that view a survey on 101 respondents owners of SMEs in rural areas was conducted, of which $79.2 \%$ were male, and $19.2 \%$ female respondents. They were offered three sets of statements that are relevant for comparison between male and female entrepreneurship and determining the characteristics of female entrepreneurship in rural areas of the Republic of Macedonia, valued at a five-degree scale from 1 - unimportant to 5 - priority. This research has shown that female entrepreneurs in rural areas by their entrepreneurial capacity do not lag behind male entrepreneurs but amazingly in some segments they show superiority. In order to enable women easier to decide on an independent path through the world of entrepreneurship legal directives should be introduced to encourage female entrepreneurship in rural areas, which would constitute the basis for implementing appropriate policy measures to support and enhance "target" policies that will be tailored to female participants. The law requires a holistic approach, shaping support measures and setting specific goals tailored to women. The publicpolitical responsibility in view of reducing and possibly overcoming the problems of gender inequality in general especially in rural areas - including employment and self employment particularly of women remains with the national systems i.e. state authorities.
\end{abstract}

Key words: female entrepreneurship; rural areas; barriers to female entrepreneurship; entrepreneurial capacity; unemployment

\section{ЖЕНСКОТО ПРЕТПРИЕМНИШТВО ВО РУРАЛНИТЕ ПОДРАЧЈА НА РЕПУБЛИКА МАКЕДОНИЈА}

Целта на овој труд е во корпусот на сознанија за женското претприемништво во руралните подрачја на Република Македонија да се инкорпорираат нови сознанија. За таа цел е спроведено анкетно истражување на 101 сопственик на МСП (мали и средни претпријатија) во руралните подрачја, од кои 79.2\% мажи, а $19.2 \%$ жени, на кои им се понудени три сета искази кои се од значење за споредба помеѓу машкото и женското претприемништво и утврдување на карактеристиките на женското претприемништво во руралните подрачја на Република Македонија, вреднувани по петостепена скала од 1 - неважно до 5 - приоритет. Истражувањето покажа дека жените претприемачи од руралните подрачја не само што по својот претприемачки капацитет воопшто не заостануваат зад претприемачите мажи туку, напротив, во некои сегменти покажуваат супериорност. За жените полесно да се одлучат на самостоен пат низ светот на претприемништвото, би требало да се донесат законски директиви за поттикнување на женското претприемништво во руралните подрачја, кои би претставувале основа за спроведување соодветни мерки на политиката за поддршка и подобри “целни" политики приспособени за жените. Законот бара холистичен пристап, обликување на мерки за поддршка и поставување на конкретни цели приспособени за жените. За намалување и надминување на проблемите со родовата нееднаквост воопшто, а особено во руралните подрачја, меѓу кои се вработувањето и особено самовработувањето на жените, одговорни се националните системи, што значи дека јавно-политичката одговорност ја сноси државата.

Клучни зборови: женско претприемништво; рурални подрачја; пречки за женско претприемништво; претприемнички капацитет; невработеност 


\section{INTRODUCTION}

Female entrepreneurship is spreading around the world and its importance grows both in the economies of developing countries and in countries with developed economies. With their actions women contribute to the development of local communities, opening opportunities and creating business areas. They also affect the way business enterprises work, shape and establish new rules of work in the business community.

Since 1990 s women's participation in the labor market has increased, as well as their contribution to the economic growth, both in the European countries in and the U.S.. Women considerably participate in the number of active population, and also in the area of education where they even surpass men. Today female entrepreneurs run between $25 \%$ and $30 \%$ of all enterprises in the world.

It is necessary to emphasize that despite the rising trend of inclusion of women in entrepreneurship, the female entrepreneurial share in Europe is still lower than the male one despite the fact that women represent majority of the population.

The impact of women in the development of entrepreneurship is valuable because of their knowledge and experience to carry the offspring and thus spread the creativity in family and general society and create conditions for successful stimulation of employment, i.e. solving the problem of unemployment.

Encouraging the presence of female entrepreneurs strengthens the economy and is a source of political, economic and social developments. SMEs owned by women according to their results demonstrate faster growth than the economy as a whole in many OECD countries. Their contribution will increase in case many obstacles are removed and their potentials exploited. It primarily refers to three main reasons (OECD1998):

- Economic: women owners of SMEs create employment for themselves and others. Many companies invest in their female members, but they do not advance to higher management positions - "effect of the glass wall." One of the possibilities for these women is to become independent and establish their own enterprises;

- Social: establishment of an own enterprise enables a woman to reconcile work and fam- ily commitments and it is a kind of a challenge for women entrepreneurs;

- Political: encouraging female entrepreneurship would contribute to the elimination of differences between men and women, increase women's autonomy and allow them to play an important active role in the economic and political life of the country.

Despite the rising trend in 1990s the share of entrepreneurs women one can conclude that it is not satisfactory both in comparison with male entrepreneurs and with the share of women in the total population. Studies have shown that women face numerous difficulties in establishing and managing enterprises. Although most of the difficulties are common to both men and women, in many instances they are more characteristic for women entrepreneurs. They are (McAtavey, J.M. 2002):

- Underdeveloped business environment;

- Choice of the type of work and sectors;

- Lack of information;

- Lack of contacts and access to networks;

- Gender discrimination and stereotypes;

- Weak and apparently inflexible supply of childcare;

- Difficulties in harmonization of responsibilities between the management of the company and the family;

- Differences in the approach towards entrepreneurship between men and women.

\section{MATERIAL AND METHODS}

The purpose of this research is based on literature, documents and especially upon an analysis of interviewed representative samples of entrepreneurs (101 SMEs), of which $79.2 \%$ owners are male, and $20.8 \%$ are women owners to gain some knowledge about the state of female entrepreneurship in rural areas in Macedonia. Several commonly used methods in the economic analysis are applied during the production of this paper, especially the method of generalization and specialization, the method of induction and deduction, the statistical method and the comparative method.

\section{RESULTS AND DISCUSSION}

The survey respondents were presented three sets of statements that are of significance for comparison between male and female entrepreneurship and determining the characteristics of female en- 
trepreneurship in rural areas of the Republic of Macedonia valued at five-level scale from 1- un- important to 5 - priority (Table 1 , Table 2 and Table 3).

\section{Table 1}

Consent with the statements in terms of improving the work for better competitive market position, compared by gender of the respondents

\begin{tabular}{llcc}
\hline \hline & & Mean value & \\
& Male & Female & Total \\
\hline Improving the quality of products and services & 4.16 & 4.11 & 4.15 \\
Improving the promotion of products & 4.18 & 4.22 & 4.19 \\
Obtaining certifications for quality & 4.04 & 3.89 & 4.01 \\
Professional consulting assistance & 3.46 & 3.39 & 3.44 \\
Improvement and education in the field of entrepreneurship & 3.85 & 3.61 & 3.80 \\
Improvement and education in the field of IT & 3.89 & 3.72 & 3.86 \\
Improvement and education in the field of management & 3.80 & 3.83 & 3.80 \\
Improvement and education in finance & 3.58 & 3.89 & 3.64 \\
Improvement and education in the field of sales & 3.82 & 4.11 & 3.88 \\
Improvement and education in marketing & 3.86 & 4.11 & 3.91 \\
Improvement and education in foreign languages & 3.30 & 3.61 & 3.36 \\
Association with companies in the sector to appear jointly on the market & 3.35 & 3.33 & 3.35 \\
Assistance from development programs through grants & 4.34 & 4.22 & 4.32 \\
Assistance from development programs through favorable loans & 4.34 & 4.17 & 4.31 \\
Assistance from development programs through guarantee funds & 3.85 & 3.56 & 3.80 \\
\hline \hline
\end{tabular}

Source: Own calculations

Table 2

Consent of claims in terms of business plans for the future, compared by gender of respondents

\begin{tabular}{lccc}
\hline \hline & \multicolumn{3}{c}{ Mean value } \\
\cline { 2 - 4 } & Male & Female & Total \\
\hline Introducing new products or services & 4.03 & 4.22 & 4.06 \\
Sales on a new market & 3.35 & 3.33 & 3.35 \\
Exploring new markets & 3.35 & 3.06 & 3.30 \\
Search for new distribution channels & 3.67 & 3.28 & 3.60 \\
Expanding advertising and promotion & 3.93 & 3.61 & 3.87 \\
Investing in new equipment and machinery & 3.73 & 3.33 & 3.65 \\
Replacement of current equipment and machinery & 3.80 & 3.22 & 3.69 \\
Expansion of current facilities & 3.75 & 3.17 & 3.64 \\
Redesign/new arrangement of the current facilities & 3.43 & 3.11 & 3.37 \\
Search for additional financial capital & 3.96 & 3.56 & 3.89 \\
Computerization of current operations & 3.29 & 3.00 & 3.23 \\
Upgrading of computer systems & 3.39 & 3.11 & 3.34 \\
Redesign of work activities & 3.31 & 3.00 & 3.26 \\
Expanding the scope of work activities & 3.84 & 3.39 & 3.76 \\
Search for professional or technical advice & 3.51 & 3.00 & 3.42 \\
Additional engagement of staff specialists & 3.39 & 3.11 & 3.34 \\
Investing in staff training (elsewhere / not in the company) & 2.63 & 2.50 & 2.60 \\
\hline \hline
\end{tabular}

Source: Own calculations 
Table 3

Agreement with statements about entrepreneurship, compared by gender of the respondents

\begin{tabular}{|c|c|c|c|}
\hline & \multicolumn{3}{|c|}{ Mean value } \\
\hline & Male & Female & Total \\
\hline My business is the most important activity in my life & 4.13 & 4.17 & 4.13 \\
\hline I would do everything that is needed for my business to succeed & 4.18 & 4.22 & 4.18 \\
\hline I plan to sell my business at the end & 2.15 & 2.17 & 2.15 \\
\hline I would like to contribute significantly to the community by developing a successful business & 4.29 & 4.33 & 4.30 \\
\hline I would prefer to have my own business than to earn higher wages working for someone else & 4.10 & 4.22 & 4.15 \\
\hline To run your own business is more important than have more time for the family & 3.80 & 3.89 & 3.82 \\
\hline I would prefer to have my own business than to have another promising career & 4.10 & 4.11 & 4.10 \\
\hline $\begin{array}{l}\text { For the entrepreneur it is important to understand and accept the risk in order to start and run a } \\
\text { successful business }\end{array}$ & 4.25 & 4.22 & 4.24 \\
\hline I am ready to get into conflict with my family for the sake of running my business & 3.71 & 3.72 & 3.71 \\
\hline I would put my house mortgaged to acquire capital for my business & 3.63 & 3.11 & 3.53 \\
\hline I would be ready to have less security for my family in order to run my business & 3.73 & 3.50 & 3.68 \\
\hline I run my business to continue the family tradition & 3.36 & 3.33 & 3.36 \\
\hline I run my business to contribute to the welfare of my relatives & 3.56 & 3.39 & 3.53 \\
\hline I run my business to live in a place that my family likes & 3.48 & 3.44 & 3.47 \\
\hline I run my business to improve the status and prestige of my family & 4.00 & 4.00 & 4.00 \\
\hline I run my business to have more flexibility in my personal and family life & 4.08 & 4.22 & 4.10 \\
\hline
\end{tabular}

Source: Own calculations

In the group of questions concerning what is necessary to improve for the company to become more competitive in the market, depending on the gender, female entrepreneurs expressed greater willingness than male ones for training and education in the field of finance, marketing, sales and foreign languages. At the same time, less female entrepreneurs than male ones expect help that would be accomplished through development programs as grants, favorable loans and guarantee funds. Male entrepreneurs are more willing to improve and become educated in the field of entrepreneurship.

What concerns the group of questions in terms of business plans for the future (regarded by gender), male entrepreneurs are those who better emphasized the need for enlargement of current facilities, request for additional financial capital, expanding the scope of work activities and request professional or technical advice. In contrast, female entrepreneurs are more inclined to add a new product or service for the market.
What concerns the group of questions concerning attitudes toward entrepreneurship, in terms of gender, female entrepreneurs are less willing to put their own property under mortgage to secure capital for their business but are more willing to do everything for success of their business. The responses to the offered statements have similar mean values both with female as well as male entrepreneurs.

The research suggests that female entrepreneurs in rural areas of the Republic of Macedonia, although are not behind male entrepreneurs by their entrepreneurial capacity, still require more or less special kinds of support from their environment. It mainly concerns forms of education and training adapted to women, favorable access to knowledge, fast paced stimulation of entrepreneurial and mentor networks for women, financing and co-financing of investments in new technologies. Understandably, these are measures developed by European countries, USA and Canada applied in supporting female entrepreneurship. 
In case faster growth of female entrepreneurship in rural areas is needed, one should understand that women require a different kind of support than men, primarily at the level of positive thinking, self-awareness, motivation and affection towards goals.

During the process of establishment of an enterprise women from rural areas should have close contacts with sources of support, including:

- Information and advice;

- Funding;

- Marketing;

- Education and training;

- Mentoring.

\section{CONCLUSION}

The trend of including women in entrepreneurship in rural areas of the Republic of Macedonia is rising, but still the share of female entrepreneurs is evidently smaller than that of male entrepreneurs. The impact of women in the development of entrepreneurship is valuable, as they represent a source of change and innovation, they contribute to solving the problem of unemployment and play a part in the development of the rural community. Running an own company offers flexibility and opportunity to harmonize the childrearing and the need for work.

In the process of establishment and management of an own company entrepreneurs do encounter numerous problems, the biggest obstacle being represented by funds. Therefore, women in rural areas mainly start small services or commercial enterprises that do not require large funds. Because the granting of small loans often bears the burden of excessive administrative costs, during the founding of a company women are forced to use their savings, as well as borrowings from relatives and friends.

This research has shown that female entrepreneurs in rural areas do not lag behind male entrepreneurs by their entrepreneurial capacity but, on the contrary, in some segments they show superiority.

In order to enable women to decide more easily for an independent path through the world of entrepreneurship legislative directives for promotion of female entrepreneurship in rural areas should be adopted, which would represent an appropriate basis for implementing policy measures for support and better "target" policies that will be tailored to the female population.

The law requires a holistic approach, shaping support measures and setting specific goals tailored to women. National systems are responsible for the reduction and overcoming of the problems with gender inequality in general, and especially in rural areas, including employment and self employment especially of women, which means that the public-political responsibility remains with state authorities.

\section{REFFERENCES}

[1] Allen Truman (1993): Women in Business, Routladge, London.

[2] Bliss R, Garat N. L, (2001): Supporting women entrepreneurs in transitioning economies, Journal of Small Business Management Milwaukee, 39 (4) 336-344.

[3] Bruni A., Gherardi S., Poggio B. (2004): Entrepreneurmentality, gender and the study of women entrepreneurs. Journal of Organizational Change Management Bradford, 17 (3), 256-268.

[4] Budig M. J. (2006): Intersections on the Road to SelfEmployment: Gender, Family and Occupational Class, Social Forcers, 84 (4), 2223-2240.

[5] Ervick Brooke R,, Margaret Langford (1998): Behaviours of Entrepreneurs: A gender Comparison. Journal of Business \& Entrepreneurship, 10, 106-115.

[6] Mcatavey J. M. (2002): Women entrepreneurs: Factors that contribute to women launching their own business and factors that satisfy women entrepreneurs. Florida: Lynn University.

[7] Moore D. P., Buttner E. H. (1997): Women Entrepreneurs: Moving Beyond the Glass Ceiling, Thousand Oaks, Ca: Sage,

[8] OECD - Organisation for Economic Cooperation and Development: Women entrepreneurs in small and medium entrepreneurship, Paris (1998). 